\title{
THE QUEST OF THE ISLAMIC ARCHIPELAGO INHERITANCE THROUGH THE JAVANESE LIVING FOLKLORE
}

\author{
Siti Masitoh \\ UIN Maulana Malik Ibrahim \\ Email: smasitoh68@yahoo.com
}

\begin{abstract}
This article is aimed at digging out the Islamic archipelago inheritance through the Javanese living folklore namely ruwatan. Ruwatan is the traditional ceremony done in order to pray to God so that the life of sukerta (one carrying bad luck) will not be under the threat of Bathara Kala. God is the only one who is able to release the sukerta's burden. The dalang (story teller) functions as a mediator of the sukerta to pray to God. Ruwatan is usually done by performing the shadow play and the dalang narrates Murwakala. There are many activities undergone by both the dalang and the sukerta before and after the performance of the shadow play. This article discusses the message of Murwakala in which the writer believes that it is not against the Islamic belief. It is a matter of fact that Murwakala was created in the 17th century anonymously so it can be assumed that it is related to the arrival of Islam in Java.
\end{abstract}

Artikel ini bertujuan menggali warisan Nusantara Islam melalui cerita rakyat orang Jawa yaitu ruwatan. Ruwatan merupakan upacara adat dalam rangka berdoa kepada Tuhan agar kehidupan sukerta (pihak yang menyandang sesuatu penyebab kesialan) tidak akan berada di bawah ancaman Bathara Kala. Tuhanlah satu-satunya yang mampu melepaskan beban sukerta. Dalang berfungsi sebagai mediator sukerta untuk berdoa kepada-Nya. Ruwatan biasanya dilakukan dengan pertunjukan wayang dan dalang mengisahkan Murwakala. Ada beberapa ritual yang dilakoni baik dalang maupun sukerta sebelum dan setelah pertunjukan wayang. Artikel ini membahas pesan Murwakala di mana 
penulis berpendapat bahwa pesan tersebut tidak bertentangan dengan keyakinan Islam. Fakta menunjukkan bahwa Murwakala diciptakan pada abad ke-17 secara anonim sehingga dapat diasumsikan bahwa itu terkait dengan masuknya Islam ke tanah Jawa.

Keywords: Folklore; Ruwatan; sukerta; Murwakala.

\section{Introduction}

Murwakala is the story performed in shadow play of Javanese traditional ceremonial namely ruwatan. Ruwatan is the Javanese traditional ceremonial done in order to release the sukerta's life from Bathara Kala's threat (Rassers, 1982: 46). There are certain group of people who believe that ruwatan is as the ceremonial that has to be done by the sukertas. Otherwise, they think that they have not done their responsibility and if they cannot do that, they will be suffered from Bathara Kala's threat (Subalidinata, 1985: 3).

There are three kinds of ruwatan that are commonly done by Javanese namely: (1) ruwatan Murwakala, it is a traditional ceremony that is done as a way of releasing the sukertas's life from Bathara Kala's threat, (2) ruwatan Makukuhan or ruwat bumi, a traditional ceremony that is done to keep yard, garden, and farmland from disaster, (3) ruwatan Sudamala, done as a way of throwing the misery off and as a way of praying to avoid from many kinds of misfortune (Rusdy, 2012: 19-32).

Furthermore, ruwatan can be undergone by: (1) serving selamatan that is usually called Ruwatan Rasulan, (2) performing Jangkung Kuning in painting shadow play, and (3) performing shadow play entitled Murwakala, it is called ruwatan Murwakala (Rusdy, 2012: 3). Ruwatan Murwakala was done for the first time in the $17^{\text {th }}$ century and it has been done from generation to generation up to now. This fact becomes an interesting literary phenomenon. Murwakala performed in ruwatan has been believed and done from time to time, in other words, it can be said that Murwakala can be accepted and understood not only by Javanese but also by other tribes from generation to generation. This fact brings the assumption that Murwakala performed in ruwatan has a universal significance and the shadow play not only shows the performance but also sends meaningful message for the audiences.

Then, according to Subalidinata (1985: 5) ruwatan can be searched by observing the actual ceremony of ruwatan or by digging out from the written sources. There are so many previous studies of ruwatan and Murwakala such as 
(1) Sejarah dan Perkembangan Cerita Murwakala dan Ruwatan dari Sumber-sumber Sastra Jawa by Subalidinata (1985), (2) Ruwatan di Daerah Surakarta by Soetarno (1995), (3) Ruwatan Murwakala: Suatu Pedoman by Karkono Kamajaya (1992), (4) Ruwatan Sukerta dan Ki Timbul Hadiprayitno by Sri Teddy-Rusdy (2012), (5) Release from Kala's Grip: Ritual Uses of Shadow Plays in Java and Bali by Ward Keeler (1992), (6) Sandhang-pangan for the Goddess: Offering to Sang Hyang Bathari Durga and Nyai Lara Kidul by Clara Brakel (1997). The above analyses have different goals and perspectives. Several of which tried to record the story of Murwakala and ruwatan from the Javanese written literature, there are also some that observed the way how the story teller (the dalang) held ruwatan ceremonial, some of which compared the text of Murwakala into Sapu Leger, and Lady Uma and the Cowherd, and the rest compared sesajen for Bathari Durga and Nyai Lara Kidul. Those analyses used Murwakala both from the written source and the actual ruwatan ceremonies in Central Java in its variant.

Then, there are two versions of Murwakala that are commonly used in holding ruwatan, those are the version of Kasunanan and the version of Mangkunegaran (Soetarno, 1995: 56). Those two versions are used not only in Central Java but also in other areas such as East Java. The previous analysis were done in Central Java, that is why, the analysis whose material object is the text of Murwakala performed in ruwatan sukerta and sengkala undergone in East Java especially from Nganjuk by Ki Suprapto HS is urgent to do.

Ki Suprapto HS learned the text of Murwakala by attending and understanding Ki Panut Darmoko's performance directly, this way is usually called as menyantrik. Ki Panut used to perform Murwakala according to Kasunanan version. Furthermore, Ki Suprapto HS deepen his understanding of Murwakala by reading Ruwatan di daerah Surakarta written by Soetarno in which there is a clear explanation about the similarities and differences between the version of Kasunanan and Mangkunegaran. This process of reading the experiences and knowledge about life told by Ki Suprapto's parents influenced the way how Ki Suprapto narrated Murwakala in ruwatan sukerta and sengkala held at January $2^{\text {nd }}, 2011$ in Nganjuk East Java. The narration of Ki Suprapto's Murwakala is different from other version, even the version of Kasunanan and Mangkunegaran. Consequently, its message will be different from others.

\section{Ki Suprapto's Murwakala and Local Wisdom}

Murwakala tells about Bathara Guru who wanted to make love to his wife, but his wife (Bathari Uma) ignored his desire because it was not in proper 
time and place causing Bathara Guru's sperm fell down the ocean. His sperm changed and grew to be a giant. He had been killed by the Gods but he was not died, he grew up strongly, and he went to Jonggring Salaka to look for his parents. Bathara Narada reminded Bathara Guru that the giant is really his son, then Bathara Narada advised Bathara Guru to acknowledge him as his son.

After being acknowledged as Bathara Guru's son, the giant was named as Bathara Kala, he was given cloths as his other brothers (Bathara Wisnu and Bathara Brama), then he was given rock and plants as his food. Unfortunately, after Bathara Kala ate the rock and plants in which there is a man fell down from the palm tree, he got fresh and healthy. That is why then Bathara Kala asked to eat man to Bathara Guru. Bathara Guru lets Bathara Kala eat men who belong to sukerta that is a group of people who can be eaten by Bathara Kala because of their unappropriate birth and their carelessness. Before leaving Jonggring Salaka, Bathara Guru wrote some notes on Bathara Kala's body, Bathara Guru told him that at any time, when there is a man who is able to read and explain the note Bathara Kala has to consider that man as his own father and he has to do his instruction. Bathara Guru also reminded Bathara Kala to kill the sukertas by using bedhama maesan (a tool given by Bathara Guru) before eating them.

In this case, Bathara Narada thought that Bathara Guru made a great mistake when he gave so many number of sukertas. It can cause the chaos. Bathara Narada suggested Bathara Guru to ask Bathara Wisnu to avoid Bathara Kala's attempt to kill and eat the sukertas by performing a shadow play. Bathara Guru agreed to Bathara Narada's suggestion, then Bathara Guru asked Bathara Wisnu, Bathara Brama, and Bathara Narada to perform a shadow play in Ngarcapada. For this purpose, Bathara Wisnu acted as Dhalang Kandhabuwana, Bathara Narada is as Panjak Kalunglungan, and Bathara Brama is as Panggender Saruni.

Knowing this fact, Bathari Uma was disappointed and protested against Bathara Guru's decision. Bathara Guru was angry because of his wife's protest then he cursed her to be a female giant. She apologizes to Bathara Guru and asked him to take his curse away. Bathara Guru refused her request. $\mathrm{He}$ suggested her to go to Ngarcapada to look for the person who is able to free her from the curse. Bathara Kala goes to Ngarcapada to look for the sukertas. During his journey, Bathara Kala met Jaka Jatusmati (a man belonging to sukerta's group because he is the only child in his family), that is why Bathara Kala wanted to kill and eat him, but Jaka Jatusmati tried to escape. Then 
Bathara Kala met Truna Bapa, another sukerta. Bathara Kala failed to kill him because Truna Bapa has stronger body than his.

Dhalang Kandhabuwana was asked by Ki Buyut Geduwal to perform a shadow play for his daughter. Bathara Kala was interested in his performance then he wanted Dhalang Kandhabuwana perform for him. Dhalang Kandhabuwana was ready to perform if Bathara Kala gave him bedhama maesan. Bathara Kala asked Dhalang Kandhabuwana who is older between Bathara Kala and Dhalang Kandhabuwana. Dhalang Kandhabuwana said that he is older than Bathara Kala, it can be proved by his ability to read and explain the note written by Bathara Guru on Bathara Kala's body. Knowing this fact, Bathara Kala admits him as his father and Bathara Kala has to do all his instructions. Then, Bathara Kala asks Dhalang Kandhabuwana to free him. After having exorcised, Bathara Kala felt healthier and not wanting to eat the sukertas anymore and he was asked to leave Ngarcapada.

Several supporting characters met Dhalang Kandhabuwana and gave message for the human being. Dewi Sri met Dhalang Kandhabuwana to give message for the woman who will cook rice to save a handful of rice. Mariyi gave a message for those who wanted to kill animals should feed them previously. All the supporting characters's message show the way how Javanese live and keep the earth. These custom or belief exist up to now and mostly used as guidance by people. Thus, in other words, it can be said that the content of Murwakala contains the Javanese wisdom.

Local wisdom can be defined as the knowledge, belief, understanding, perception, custom or ethics that guide human attitude how to live in a certain ecological communities (Keraf, 2002) while according to Gobyah (2009) local wisdom is related to the truth that has been stable in a certain area. Referring to those two definitions, local wisdom can be stated as a value that is considered as goodness or the truth that has been undergoing from generation to generation. In addition, it has been done by the involved society as a result of the interaction between human being with their surroundings.

The Javanese local wisdom described in Murwakala can be seen through the existence of all characters both main and supporting characters and their relationship. The Javanese local wisdom can be classified into: (1) the Javanese ethics of coitus, (2) the Javanese ethics of family, (3) the Javanese ethics of a work, (4) the Javanese ethics of killing the animal, (5) the Javanese ethics of being a leader, (6) the Javanese way of living in a community, and (7) the 
Javanese concept of life. The evidences of the above idea can be explained as follows:

\section{First, the Javanese ethics of coitus.}

The text of Murwakala is started by presenting a meeting done in Jonggring Salaka (the place where Bathara Guru and his family are living). The meeting aimed at discussing the chaos happens in kayangan (heaven). Bathara Guru asked Bathara Narada to explain the cause of the chaos. Bathara Narada said that the chaos was caused by the appearance of a giant who was looking for his parents. Bathara Narada suggested Bathara Guru to acknowledge him as his son. Bathara Narada reminded Bathara Guru about the mistake done by Bathara Guru when during twilight. Bathara Guru and his wife (Bathari Uma) were riding lembu Andini, when he wanted to make love with his wife but it was rejected by Bathari Uma because it was not in a right time and place. It caused Bathara Guru's sperm fell down the ocean and it grew up to be a giant who like eating human being. Bathara Kala had bad attitude because of his wrong birth, he was not born in a common way as his other brothers, Bathara Wisnu and Bathara Brama. In short, it can be stated that Bathara Kala appears because of Bathara Guru's failure to restrain his desire. Bathari Uma's decision to refuse her busband's desire can be accepted by the Javanese because the Javanese believe that when the couple (husband and wife) want to make love, they have to pay attention on time and place. They are not allowed to make love at any time and in an open space.

\section{Second, the Javanese ethics of the family}

The Javanese ethics of the family is presented by the relationship between husband and wife, Bathara Guru and Bathari Uma. Bathari Uma is accused of making mistake when she refused his husband's desire and when she protested against Bathara Guru's decision to send Bathara Wisnu to avoid Bathara Kala's attack human being by performing a shadow play. Her protest is considered as impolite attitude because the Javanese think that a wife is not allowed to protest her husband. A wife should do whatever her husband wants or asks.

\section{Third, the Javanese ethics of a work}

The Javanese ethics of a work is presented by the characters who worked as thiefs. They steal to survive their life. Dhalang Kandhabuwana asked them not to steal anymore because it is not good. They have to look for a good job 
that does not damage or harm others. They have to get the income in right and proper way.

\section{Fourth, the Javanese ethics of killing the animal}

The Javanese have a certain way to kill the animal. This event is described by the appearance of Mariyi who came to meet Dhalang Kandhabuwana in order to give a message for the next generation who will kill animals. They have to feed those animals before killing them.

\section{Fifth, the Javanese ethics of being a leader}

A leader in Murwakala is presented by Dhalang Kandhabuwana. When he was performing a shadow play, the thiefs came to ask him to protect them from the people's chase. Knowing that fact, Dhalang Kandhabuwana asked them to join with other gamelan players (niyaga) and told the people to go away because there is no thief in the performance area. After the people left the area, Dhalang Kandhabuwana advised them not to steal anymore. This event shows how the leader has to protect his staff when he is in a problem then it is also his responsibility to remind them when they make mistake.

\section{Sixth, the Javanese way of living in a community}

There is a habit usually undergone by the Javanese that is called as gotong royong, the Javanese tend to work together. This event is presented by Suwarno who came to Dhalang Kandhabuwana to perform a shadow play for his son's exorcism so they will not be attacked by Bathara Kala. Dhalang Kandhabuwana explained that the cost of performing the shadow play is very expensive that is why Dhalang Kandhabuwana suggested him to join ruwatan masal by which the expenses of ruwatan are paid by some people. Suwarno agreed to his suggestion so he joined the ruwatan masal which characterize the principle of gotong royong.

Until today, any old Javanese women are also accustomed to save handful of rice when they cook rice. It is in accordance with the message of Dewi Sri who came to Dhalang Kandhabuwana to tell the next generation to save handful of rice when they cook rice. They can use the accumulated rice for slametan (eating together with the neighborhood). 


\section{Seventh, the Javanese concept of life.}

The Javanese concept of life is the concept of Sangkan paraning dumadi that is the way how Javanese have a look of themselves by asking themselves or reflecting on where they are from and what the goal of their life is. The Javanese believe that they are from nothing and they will be back to nothing, as it is stated by Dhalang Kandhabuwana after he frees Bathara Kala from exorcise. Murwakala basically tells about Bathara Kala's journey to quest of self-identity, Bathara Kala is effortful to look for the sukertas up to his meeting with Dhalang Kandhabuwana. Bathara Kala was successful in his quest of self-identity, he is admitted as the son of Bathara Guru and finally he is also successful of being a good one, he does not attack the sukertas anymore because he does not need to eat human being.

\section{Conclusion}

Murwakala is rich of Javanese local wisdom and its content can be accepted by the people from generation to generation because it is telling about human existence particularly on the Javanese way of looking at themselves. It is the way how Javanese manage and control themselves in their life. Unfortunately, there are a group of people consider Murwakala as a holy story so this story cannot be told by common people at any performance of shadow play so it cannot be enjoyed by people in large number. Hopefully, by observing it scientifically and sharing it, the local wisdom of Murwakala will be read by greater number of people. It is also expected that there will be more studies focusing on the interpretation of Murwakala from various Islamic perspective.

\section{References}

Gobyah, IK. 2009. Berpijak pada Kearifan Lokal. Available at http://www. balipos.co.id/

Keraf, S. 2002. Etika Lingkungan. Jakarta: Penerbit Buku Kompas

Rassers, W.H. 1982. Panji, the Culture Hero: a Structural Study of Religion in Java. The Hague: Martinus Nijhoff.

Rusdy, S.T. 2012. Ruwatan Sukerta dan Ki Timbul Hadiprayitno. Jakarta: Yayasan Kertagama. 
Subalidinata, et.al.1985. Sejarah dan Perkembangan Cerita Murwakala dan Ruwatan dari sumber-sumber Sastra Jawa. Yogyakarta: Departemen Pendidikan dan Kebudayaan. Direktorat Jendral Kebudayaan.

Soetarno.1995.Ruwatan di Daerah Surakarta.Surakarta: CV. Cendrawasih. 
